\title{
ОСОБЛИВОСТІ ОРГАНІЗАЦІЇ МЕДИКО-ПСИХОЛОІЧНОЇ РЕАБІЛІТАЦІЇ ВІЙСЬКОВОСЛУЖБОВЦІВ В КРАЇНАХ-ЧЛЕНАХ ТА ПАРТНЕРАХ НАТО
}

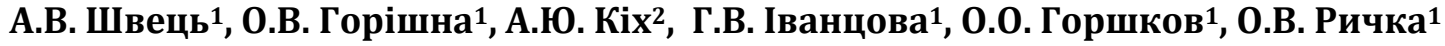 \\ ${ }^{1}$ Науково-дослідний інститут проблем військової медицини \\ Української військово-медичної академії, м. Київ, Україна \\ ${ }^{2}$ Військово-медичний клінічний лікувально-реабілітаційний центр, м. Ірпінь, Украӥна
}

\begin{abstract}
Мета. Дослідити різні аспекти організації медико-психологічної реабілітації військовослужбовців в країнах-членах та партнерах НАТО.

Матеріали та методи. 3 використанням методів системного, бібліосемантичного та ретроспективного аналізу вивчено наукові публікації щодо виявлення особливостей організації медикопсихологічної реабілітації військовослужбовців в США, Канади, Німеччини, Франції, Великобританії, Ізраїлю. Для цього здійснено пошук доступних джерел інформації з 1995 по 2017 роки, які стосувались мети роботи та термінологічних фраз «Рsycho-medical aid», «Psycho-medical rehabilitation», «Medical rehabilitation», «Psychiatric rehabilitation», «Psychological Rehabilitation». На основі thoughtful-аналізу сучасних джерел інформації було узагальнено різні підходи до формування та підтримки належного рівня ментального здоров'я з метою розробки та удосконалення вітчизняних заходів медико-психологічної реабілітації військовослужбовців.
\end{abstract}

Результати. Виявлено особливості організації медико-психологічної реабілітації військовослужбовців в ЗС США, Канади, Німеччини, Франції, Великобританії, Ізраїлю. Показано важливість науково-методичного забезпечення системи контролю бойового стресу армії США, яке забезпечують наукові центри з контролю бойового і військово-професійного стресу родів військ, а також провідні наукові університетські центри США. Найбільш активними учасниками дослідницьких програм з проблем ПТСР в США є Національний інститут психічного здоров'я (NIMH), Національний центр з проблем ПTCP (US Department of Veterans Affairs), Центр психологічного здоров'я Міноборони (DCEPH TBI DCoE), Військовомедичний університет (USUHS), Військовий інститут ім. Уолтера Ріда (WRAIR). Наголошено про необхідність впровадження сучасних інструментів скринінгу ефективності реабілітації (шкала Ренкіна, спеціальні комп'ютерні програми тощо) з урахуванням Міжнародної класифікації функціонування $i$ обмеження життєдіяльності. Основною тенденцією щодо організації ефективної системи збереження психічного здоров'я військовослужбовців збройних сил країн Альянсу $\epsilon$ впровадження відповідних тренінгових програм щодо підвищення рівня психологічної стійкості особового складу, розширення серед військовослужбовців знань про когнітивні, поведінкові та фізіологічні процеси в умовах бойової діяльності, нормалізацію реакції на стрес, забезпечення військовослужбовців ефективними копінг-стратегіями подолання стресу і надання допомоги командирам щодо підтримки та зміцнення психічного здоров'я підлеглих.

Висновки. Показано, що прояви як самого бойового і військово-професійного стресу, так $i$ його дезадаптивних реакцій, а також умови їх виникнення не тільки підвищують ризики несприятливого перебігу бойових поранень, але й суттєво впливають на перебіг їх наслідків з боку психічного та фізичного здоров'я. Тому зазначений аспект організації медико-психологічної реабілітації за досвідом організації медико-психологічної реабілітації військовослужбовців в збройних силах провідних країн-членів та партнерів НАТО є одним з принципових для впровадження в ЗС України. Потребують детального вивчення на практичному (натурному) рівні техніки психологічної допомоги на 1-му рівні (ешелоні), які за досвідом ЗС Великобританії, дозволяють суттєво зберегти психічне здоров'я військовослужбовців. Показано, що однією з важливих складових якісної реабілітації, $\epsilon$ побудова ефективної комунікації між системою здійснення лікувально-евакуаційного процесу постраждалих від фізичних травм та поранень, орієнтованою на соматичні показання і критерії та елементами системи охорони психічного здоров'я військовослужбовців. Такий аспект є актуальним на всіх рівнях надання медичної допомоги. Назріла необхідність удосконалення державної системи комплексної реабілітації військовослужбовців, які беруть або брали участь в бойових діях та перенесли бойові та військово-професійні травми та поранення, а саме в частині, що стосується як програмних заходів, так і методів контролю ефективності та якості проведеної реабілітації. Це дозволить цілеспрямовано здійснювати заходи щодо забезпечення збереження фізичного і психічного здоров'я військовослужбовців, забезпечить профілактику ПСТР, буде сприяти підтримці готовності особового складу до виконання завдань за будь-яких змін обстановки.

Ключові слова: медико-психологічна реабілітація, медико-психологічний супровід, психічне здоров'я. 
Вступ. Дані літературних джерел свідчать про те, що кожен п'ятий учасник бойових дій, навіть при відсутності фізичної травми, страждає від невротичних розладів, а через декілька місяців після повернення до нормальних умов життя у нього проявляються інші наслідки - різноманітні психосоматичні захворювання. До змінених психічних станів, що можуть виникати у військовослужбовців у період ведення бойових дій, відносять: бойову стресову реакцію (початковий прояв розладів адаптації), бойову втому та посттравматичний стресовий розлад, а також реактивні стани як найтяжчі форми бойової психіатричної патології. У результаті такого значного негативного впливу факторів бойової діяльності, близько 90\% військовослужбовців потребують комплексної медикопсихологічної реабілітації [13]. Це вказує на актуальність розробки нових підходів до реабілітації військовослужбовців Збройних Сил України. Саме тому важливим $є$ вивчення зарубіжного досвіду реабілітації означеної категорії, оскільки він є цінним і перевіреним на практиці.

Мета роботи. Дослідити різні аспекти організації медико-психологічної реабілітації військовослужбовців в країнах-членах та партнерах НАТО.

Матеріали та методи дослідження. 3 використанням методів системного, бібліосемантичного та ретроспективного аналізу вивчено наукові публікації щодо виявлення особливостей організації медикопсихологічної військовослужбовців в США, Канади, Німеччини, Франції, Великобританії, Ізраїлю. Для цього здійснено пошук доступних джерел інформації з 1995 по 2017 роки, які стосувались мети роботи та термінологічних фраз «Psycho-medical aid», «Psycho-medical rehabilitation», «Medical rehabilitation», «Psychiatric rehabilitation», «Psychological Rehabilitation». На основі thoughtful-аналізу сучасних джерел інформації було узагальнено різні підходи до формування та підтримки належного рівня ментального здоров'я для розробки та удосконалення вітчизняних заходів медико-психологічної реабілітації військовослужбовців.

Результати та їх обговорення.

Досвід медико-психологічної реабілітації військовослужбовців у Сполучених Штатах Америки.

Організація медико-психологічної реабілітації учасників локальних збройних конфліктів у Сполучених Штатах Америки (надалі - США) сьогодні $\epsilon$ найбільш прогресивною, що дає можливість суттєво зменшити чисельність осіб, які страждають розладами психіки. В армії США розроблена і постійно удосконалюється комплексна i багаторівнева система контролю бойового i військово-професійного стресу (Combat and Operational Stress Control, COSC), що включає не тільки спеціальні підрозділи та бюджетні установи, але й армійські структури всіх рівнів і організації членів сімей військовослужбовців [4]. 32016 року в військах США, згідно 3 програмою розвитку армії майбутнього «Збройні Сили 2025» (Force 2015 and beyond, F2025B), запущена система постійного вдосконалення боєготовності підрозділів ARFORGEN (Army Force Generation), що спрямована на циклічне відтворення добре навчених і добре організованих підрозділів, які проходять підготовку як єдині колективи [22].

На рівні військової ланки система контролю COSC (Combat and Operational Stress Reaction) складається 3 загальноармійської програми комплексної психофізіологічної підготовки військовослужбовців, членів їх сімей (Comprehensive Soldier and Family Fitness, CSF2) і постійного моніторингу психічного стану військовослужбовців, навчання, тренувань, консультацій і надання долікарської допомоги молодшими командирами, медиками (аналог санінструктора в 3С України), капеланами (священиками) i солдатами-наставниками (загальна назва - Master Resilience Trainers, MRTs), які пройшли навчання у спеціальних навчальних центрах [23].

У структурі медичної служби армії США на рівні дивізій, бригад функціонують мобільні підрозділи психічного здоров'я (Mental Health Section, MHS), до складу яких входять 8 осіб: дивізійний психіатр (майор), соціальний психолог (капітан), клінічний психолог (капітан), адміністратор (унтерофіцер) і 4 асистенти (середній медичний персонал). Основні завдання підрозділів MHS полягають у навчанні військовослужбовців способам підвищення психологічної стійкості в рамках програми CSF2, проведенні моніторингу психічного здоров'я та виявлення військовослужбовців, які потребують кваліфікованої допомоги, здійснення короткострокових втручань на догоспітальному етапі, реабілітація і супровід комбатантів, медичне сортування комбатантів 
3 гострими психічними розладами і підготовка їх до евакуації в профільні медичні установи, а також проведення заходів щодо відновлення боєздатності військових підрозділів.

На рівні корпусів функціонують мобільні підрозділи контролю бойового стресу (Combat Stress Control, CSC), що складаються 3 управління та відділень профілактики та реабілітації. До складу управління входить командир (підполковник), капелан (капітан), помічник командира 3 медичної частини (капітан або старший лейтенант), старшина підрозділу, адміністратори для роботи з пацієнтами (унтер-офіцери), фахівець 3 хімзахисту i технічний персонал (сержантський i рядовий персонал). Організаційно-штатна структура профілактичного відділення складається з 16 осіб (4 соціальні психологи (2 майори і 2 капітани), 4 клінічні психологи (2 майори і 2 капітани), 4 адміністратори (унтер-офіцери) і 4 асистенти (середній медичний персонал). Організаційно-штатна структура реабілітаційного відділення складається 320 осіб (2 психіатри (підполковник і майор), профпатолог (майор), медбрат (майор), адміністратор (унтер-офіцер) і 8 асистентів (унтер-офіцери і сержанти)). Ці підрозділи можуть посилювати передові структури медичної служби, госпіталів і MHS військової ланки. Вони забезпечують розгортання наметів медико-психологічної допомоги та реабілітації для короткострокової допомоги військовослужбовцям при проявах бойового стресу, а також працюють в якості психіатричних відділень госпіталів, які забезпечують зону бойових дій. Крім цього, підрозділи CSC надають допомогу командуванню щодо моніторингу ситуації, планування та координації сил і засобів для надання медико-психологічної допомоги при бойовому стресі.

На рівні армійського командування США діють аналітичні групи щодо оцінки бойового стресу на театрі бойових дій (Operational Stress Assessment Team, OSAT), що формуються 3 фахівців Армійського дослідного інституту ім. Уолтера Ріда, Військово-повітряної медичної дослідницької лабораторії, Медичного дослідницького інституту хімічного захисту та Дослідницького інституту військової гігієни США. Організаційно-штатна структура аналітичної групи включає 3-х психологівдослідників або психіатрів 3 досвідом дослідницької роботи (офіцери), 2 фахівців 3 психічного здоров'я сержантського або рядового складу і фахівців 3 інформаційних технологій. До завдань фахівців OSAT входять проведення макроаналізу факторів бойового стресу, оцінка стану військовослужбовців на рівні військових підрозділів і прогнозування потреб в наданні медико-психологічної допомоги на театрі бойових дій.

Науково-методичне забезпечення системи контролю бойового стресу армії США забезпечують наукові центри 3 контролю бойового i військово-професійного стресу родів військ і провідні наукові університетські центри США. Найбільш активними учасниками дослідницьких програм з проблем ПТСР в США $є$ Національний інститут психічного здоров'я (NIMH), Національний центр 3 проблем ПТСР (US Department of Veterans Affairs), Центр психологічного здоров'я Міноборони (DCEPH TBI DCoE), Військово-медичний університет (USUHS), Військовий інститут ім. Уолтера Ріда (WRAIR).

Командування армії США ставить наступні завдання щодо вдосконалення системи контролю бойового стресу (на прикладі корпусу морської піхоти) [7]:

а) підвищення боєздатності та боєготовності підрозділів за рахунок профілактики, раннього виявлення і корекції ознак бойового стресу;

б) підвищення переносимості бойового стресу, розвиток у військовослужбовців і членів їх сімей механізмів психологічної стійкості шляхом набуття і застосування на практиці спеціальних психологічних знань, навичок i умінь для управління своїм психофізіологічним станом і психологічною атмосферою в підрозділі та сім'ї;

в) реалізація 5-ти основних елементів системи контролю бойового стресу у військовослужбовців на рівні командування військових підрозділів: зміцнення психологічної стійкості, профілактика психотравмуючих факторів бойового стресу i своєчасна корекція його ознак, раннє виявлення дезадаптивних стресових реакцій, проведення стандартного 7-ми етапного комплексу першої допомоги при бойовому стресі (табл.1), направлення, за необхідності, для надання кваліфікованої короткострокової і медико-психологічної допомоги протягом 2472 год., підтримка при реінтеграції комбатанта в підрозділі;

г) створення в підрозділах умов і атмосфери, в яких військовослужбовці можуть вільно звертатися за допомогою при дезадаптивних реакціях при бойовому стресі. 
Департамент у справах ветеранів США має багато спроможностей для збереження психічного здоров'я ветеранів, у т.ч. 150 медичних центрів, 819 амбулаторних клінік, 300 центрів ветеранів, кризова лінія для ветеранів, представники Департаменту в університетських кампусах та інші інформаційно-просвітницькі структури. Це дозволяє забезпечувати доказове спеціалізоване лікування ветеранів у стаціонарах, лікарнях за місцем проживання та в амбулаторіях з можливістю лікування ПТСР; лікування осіб, що зловживають наркотиками та алкоголем; лікування серйозних психічних розладів, а також забезпечувати загальні послуги 3 відновлення психічного здоров'я [12]. У реабілітаційних центрах працюють мультидисциплінарні команди, що передбачає тісну співпрацю психіатрів, психологів, соціальних працівників, сімейних терапевтів тощо.

Таблиця 1

Семиетапний комплекс допомоги військовослужбовцям при бойовому стресі в армії CША «7 Cs»

\begin{tabular}{|c|c|}
\hline Вид допомоги & Етапи надання допомоги \\
\hline Перша допомога & Check - оцінка стану та проведення спостереження \\
\cline { 2 - 2 } & $\begin{array}{c}\text { Coordinate - при необхідності переконання звернутися за } \\
\text { кваліфікованою допомогою та координування ї̈ надання }\end{array}$ \\
\cline { 2 - 2 } & $\begin{array}{c}\text { Cover - миттєве забезпечення безпеки для життя та усунення } \\
\text { стресора }\end{array}$ \\
\cline { 2 - 2 } & Calm - заспокоєння, від реагування емоції, перемикання уваги \\
\hline Реабілітація & $\begin{array}{c}\text { Connect - забезпечення контакту та підтримка з боку службовців, } \\
\text { друзів, рідних, близьких }\end{array}$ \\
\cline { 2 - 2 } & Competence - відновлення професійних навичок і вмінь \\
\cline { 2 - 2 } & Confidence - відновлення відчуття впевненості у собі \\
\hline
\end{tabular}

Департаментом у справах ветеранів спільно 3 Міністерством оборони США розроблено детальні науково обгрунтовані протоколи надання психотерапевтичної та фармакологічної допомоги на різних етапах: від запобігання травмам до складних $\mathrm{i}$ хронічних проявів ПТСР зі стійкими симптомами, що потребують комплексного й гнучкого підходу до лікування.

Варто зазначити, що в окремих учасників бойових дій спостерігається також і феномен посттравматичного загострення особистості. Щоправда, емпіричні дослідження цього феномену проводили переважно учені США, фокусуючись на ветеранах війн у Перській затоці, Іраку та афганської операції «Нескорена свобода». Останнім часом, завдяки адаптації зарубіжних методик почали з'являтися i перші українські емпіричні дослідження з цієї тематики, що також має велике значення для пошуку нових шляхів розвитку державної системи збереження психічного здоров'я військовослужбовців [20].

Досвід медико-психологічної реабілітації військовослужбовців Канади.

До складу служби охорони здоров'я збройних сил Канади входить мережа 37 медичних центрів травматології та стресу (Ottawa ON, Valcartier Qc, Petawawa ON, Gagetown NB, Halifax NS, Edmonton AB i
Esquimalt BC) [28]. Програма фізичної реабілітації військовослужбовців у збройних силах Канади [18] включає в себе медикопсихологічну реабілітацію та надання послуг соціально-психологічного характеру в медичних центрах, що наближені до сім'ї. Реабілітація проводиться у військових центрах реабілітації, що поєднані 3 академічними цивільними центрами 3 передовим досвідом. Організація медичної допомоги та реабілітації побудована також на грунті диференційованого підходу до біологічних i небіологічних факторів. Канадськими ерготерапевтами розроблена біо-психосоціально-духовна модель 3 реабілітаційної медицини, що ілюструє стосунки між людиною (фізичним, когнітивним, афективним та духовним вимірами), середовищем існування людини (фізичним, культурним, інституційним i соціальним вимірами) та іiі професійною діяльністю (самообслуговування, продуктивність та відпочинок) [19, 31, 32, 33].

Ветерани можуть отримати підтримку 3 психічного здоров'я в рамках двох програм Канади у справах ветеранів: програми допомоги по інвалідності та Служби реабілітації і професійної допомоги. Тільки звільнені учасники бойових дій мають право на отримання пільг за програмою реабілітації 
Veterans Affairs Canada. В рамках «Програми допомоги по інвалідності» допомога по інвалідності виплачується ветеранам, які мають на це право, в тому числі військовослужбовцям збройних сил Канади, які мають хронічні захворювання, пов'язані зі службою, в тому числі психічні розлади. Програма реабілітації та професійної допомоги, яка, як правило, надає тимчасову, а не постійну підтримку, спрямована на те, щоб допомогти ветеранам максимально поліпшити своє здоров'я і пристосуватися до життя вдома, в суспільстві та на роботі [27].

У Канаді для ветеранів передбачена мережу клінік по роботі зі стресовими травмами; послуги з ведення справ; телефонна служба допомоги; програма соціальної підтримки при стресі [27]. Кожен ветеран, включений до програми реабілітації, знаходиться під опікою куратора, який визначає потребу в психіатричній допомозі, готує план допомоги та стежить за прогресом ветерана.

Досвід медико-психологічної реабілітацї військовослужбовців Німеччини.

У Німеччині забезпечення заходів із підтримки, поліпшення і відновлення працездатності здійснюють представники пенсійного страхування робітників i службовців. У сфері соціально-професійної реабілітації монопольне місце належить федеральному відомству з питань страхування і працевлаштування безробітних [15]. Питанням фінансування заходів із реабілітації займаються виключно органи соціального страхування на місцях. Німецькі реабілітаційні центри, залежно від пріоритету медичної або соціальної реабілітації, передбачають два рівні. Реабілітаційний центр першого рівня практично $€$ реабілітаційною клінікою, де переважає медична реабілітація. Однак у таких центрах є майстерні, зали для навчання роботі на комп'ютерах, кухні, де клієнти отримують елементи соціально-побутової та професійної реабілітації. Ці центри, здебільшого, $є$ спеціалізованими за профілем патології: психологічні, неврологічні тощо. До структури такого центру можуть входити підрозділи, що займаються питаннями соціальної реабілітації, наприклад, відділ професійної реабілітації, завданням якого $є$ надання професійних умінь і навичок реабілітантам за певними спеціальностями (програмування, електротехніка, креслення, торгові професії тощо) i соціальна служба, працівники якої допомагають організувати дозвілля клієнтам
Центру, відповідають за їхню адаптацію в суспільстві після виписки, навчають робити покупки.

На даний час керівництво Міністерства оборони Німеччини приділяє більше уваги питанню організації ефективного психологічного забезпечення у збройних силах, яке проводиться із метою виховання в особового складу психологічної готовності до виконання поставлених завдань як у процесі загальної діяльності, так і в умовах бойового застосування військ (сил) [9]. Одними із завдань психологічного забезпечення, що покладені на психологічну службу $є$ [9]: надання військовослужбовцям спеціалізованої допомоги щодо соціальної адаптації, самореалізації у повсякденному житті, а також у подоланні складних психотравмуючих ситуацій під час та після бойових дій; надання практичної допомоги командирам підрозділів 3 питань індивідуальної та колективної роботи 3 особовим складом. Основними видами діяльності психологічного забезпечення збройних сил Німеччини $\epsilon$ [9]: тестування кандидатів на військову службу 3 метою раннього виявлення психічних розладів; індивідуальне психологічне консультування; психологічна підтримка та супровід; психологічний аналіз і корекція; поглиблена психологічна реабілітація.

На спеціалістів-психологів військової ланки покладені завдання щодо психологічної профілактики серед особового складу, а також проведення індивідуальних психологічних консультацій та психологічного аналізу. У разі виявлення тяжких психологічних порушень постраждалих направляють до спеціалістів госпітальної ланки 3 подальшим психотерапевтичним (психіатричним) лікуванням. У госпітальному підрозділі надають допомогу лікарі-психотерапевти та психіатри [8]. У Німеччині створено спеціалізовані центри для військовослужбовців з травмованою психікою та Центр вивчення ПТСР в Берліні. У країні також працює телефонна «гаряча» лінія, яка цілодобово надає психологічні консультації військовослужбовцям [9]. Для надання спеціалізованої допомоги постраждалим військовослужбовцям у Берліні створено Центр вивчення проблем медикопсихологічної реабілітації особового складу Бундесверу. Крім того, командування збройними силами Німеччини прийняло рішення щодо їх оснащення мобільними 
контейнерними

лабораторіями для проведення ранньої діагностики психологічних розладів у військовослужбовців, що беруть участь у бойових діях за межами країни [9].

Досвід медико-психологічної реабілітації військовослужбовців Франції.

На даний момент на території Франції налічується 817 секторів загальної психіатрії для дорослих, 321 дитячої та підліткової психіатрії, і 26 для ув'язнених. 3 них $65 \%$ прикріплені до спеціалізованого госпітального центру, а 35 \% - до загального або університетського госпітального центру. Кожен сектор складається 3 лікувальних підрозділів, таких як госпітальний спеціалізований центр, медико-психологічний центр, денний стаціонар, центр повної госпіталізації, центр амбулаторного прийому, центр реабілітації та ін. Мультидисциплінарні бригади забезпечують превентивні заходи, первинну медичну допомогу, профільне лікування та подальшу соціальну інтеграцію хворих на підвідомчій території [11]. Лікування без госпіталізації організоване за двома напрямками: структури прийому i орієнтації відкритого типу, а також структури для реабілітації пацієнтів. Важливу роль в наданні допомоги без госпіталізації відіграють медико-психологічні центри (МПЦ). Зазвичай вони розташовуються поза госпіталями i забезпечують консультації всім бажаючим за направленням лікаря або за власною ініціативою. МПЦ не тільки консультують, а й проводять амбулаторне лікування, візити додому. Вони забезпечують післягоспітальну терапію і соціальну інтеграцію. Первинний і поточний прийом здійснюють медичні сестри, які «ведуть» пацієнтів, координують зустрічі з психіатром, психологом, соціальними працівниками, спільно 3 лікарями розробляють проект лікування, виконують необхідну адміністративну та фінансову роботу, допомагають пацієнтам в організації повсякденного життя в інтересах терапії.

Існують також такі «незвичайні» структури, що для зручності можна назвати «терапевтичні квартири». Їх завдання полягає у поверненні пацієнтів до повноцінного соціального життя. Структура надає житло декільком особам 3 важким психіатричним діагнозом (в місті чи сільській місцевості) на обмежений період часу i під медичним наглядом. Кожен учасник проекту залучений до вирішення побутових питань повсякденного (прання/прибирання/харчування) всередині і зовні. У цьому випадку місце проживання $\epsilon$ терапевтичним інструментом у поєднанні 3 медикаментозним i психологічним лікуванням в МПЦ. Результати даного виду терапії позитивні, але досить складні в організаційному плані [11].

Досвід медико-психологічної реабілітації військовослужбовців Великобританії..

На основі багатьох масштабних i системних досліджень у збройних силах Великобританії сформовано нове стратегічне бачення щодо ключових завдань та організаційної структури комплексної системи збереження психічного здоров'я військовослужбовців. Ця система одночасно відображає передові наукові надбання цивільних фахівців щодо збереження психічного здоров'я та враховує всі аспекти військової специфіки [33]. Вона має чотири основні напрями, які мають власні розроблені алгоритми їх реалізації, а саме: збереження психічного здоров'я військовослужбовців у пунктах постійної дислокації підрозділів збройних сил i виконання службових обов'язків в умовах повсякденної діяльності; збереження психічного здоров'я військовослужбовців в умовах розгортання військ і виконання підрозділами бойових завдань; збереження психічного здоров'я резервістів під час проходження регулярної військової підготовки й повернення їх до цивільного життя; заходи зі збереження психічного здоров'я, спрямовані на осіб, які завершили військову службу (ветеранів).

Під час перебування у пунктах дислокації військових підрозділів більшість заходів щодо збереження психічного здоров'я проводяться шляхом застосування імпліцитарних заходів. Для цього створена мережа неформальної підтримки, метою якої $є$ виявлення і корекція проблем психічного здоров'я. Функціонування цієї мережі забезпечують фахівці немедичного профілю. Зазвичай це офіцери із соціального забезпечення (welfare officers), спеціалісти по роботі з сім'ями (family officers), капелани та військовослужбовці - практики TRiM (Trauma Risk Management). Практиками TRiM $\epsilon$ переважно добровольці, унтер-офіцери, які мають суттєвий військовий досвід, пройшли навчання з оцінювання психологічних ризиків і володіють базовими знаннями щодо природи психічної травматизації [33]. Система психологічної підтримки і нагляду з боку співробітників TRiM створена, щоб допомагати військовослужбовцям, які мають 
психологічні проблеми звернутися за допомогою до фахівців зі збереження психічного здоров'я [3].

Під час перебування у зоні бойових дій, як і в постійних пунктах дислокації, наряду 3 фахівцями TRiM до захисту психічного здоров'я військовослужбовців долучаються спеціалісти «польових команд 3 охорони психічного здоров'я» (field mental health teams, FMHT), основне завдання яких полягає у диференціації військовослужбовців на тих, які здатні подолати психологічні проблеми i залишаються виконувати завдання у зоні бойової діяльності, і тих, які потребують обов'язкової евакуації. Повертаючись із зони бойової діяльності, підрозділи обов'язково проходять фазу декомпенсації на острові Кіпр, що полегшує процес адаптації до умов звичайного життя. Фаза декомпенсації триває від трьох до чотирьох днів і включає: усвідомлення того, що було досягнуто; контекстуалізацію минулого досвіду, що дає можливість своєчасно розпочати адаптацію переходу від діяльності у бойових умовах до мирного життя; керування очікуваннями щодо повернення до постійного місця перебування [25]. Особовий склад підрозділів інформують про можливі наслідки бойового стресу, а за окремими військовослужбовцями, які входять до «групи ризику» щодо психічного здоров'я, спостерігають фахівці зі збереження психічного здоров'я i, при необхідності надають необхідну професійну допомогу. В цей період неформальну підтримку також надають капелани [25].

Серед ключових складових у структурі системи збереження психічного здоров'я у збройних силах Великої Британії варто зазначити «Районні відділи психічного здоров'я» (Departments of Community Mental Health, DCMH), до складу яких входять консультанти-психіатри, медичні сестри 3 психічного здоров'я, соціальні працівники 3 питань психологічного здоров'я, а також, якщо виникне необхідність, клінічні психологи. Основним завданням таких відділів $\epsilon$ підтримка військовослужбовців збройних сил i своєчасне направлення їх на стаціонарне лікування. Також фахівці «районних відділів психічного здоров'я» беруть участь у наданні послуг щодо забезпечення психічного здоров'я у хірургічних відділеннях, включаючи Медичний реабілітаційний центр збройних сил Великої Британії та Королівський центр військової медицини [30].
Для збереження психічного здоров'я резервістів під час проходження регулярної військової підготовки і повернення їх до цивільного життя у Великобританії розроблена «Програма зі збереження психічного здоров'я резервістів» (Reserves Mental Health Program, RMHP). Завдяки цій програмі мобілізовані резервісти отримують таку ж психіатричну допомогу, як і постійно діючий особовий склад [33]. Важливою складовою системи збереження психічного здоров'я у збройних силах Великобританії $\epsilon$ науково-дослідні установи, які регулярно відслідковують ефективність усіх заходів зі збереження психічного здоров'я військовослужбовців i надають пропозиції щодо їх удосконалення.

Однією із сучасних тенденцій щодо організації ефективної системи збереження психічного здоров'я військовослужбовців збройних сил Великобританії та інших країн Альянсу $\epsilon$ впровадження відповідних тренінгових програм щодо підвищення рівня психологічної стійкості особового складу, розширення серед військовослужбовців знань про когнітивні, поведінкові та фізіологічні процеси в умовах бойової діяльності, нормалізацію реакції на стрес, забезпечення військовослужбовців ефективними копінгстратегіями подолання стресу i надання допомоги командирам щодо підтримки та зміцнення психічного здоров'я підлеглих [20].

Досвід медико-психологічної реабілітації військовослужбовців Ізраӥлю.

Досвід Ізраїлю особливо цікавий для України, адже ця країна веде бойові дії вже кілька десятиліть, і тут чи не найкраща в світі організація психологічної допомоги військовослужбовцям, ветеранам, і членам їхніх родин. Ще під час війни з Ліваном у 1982 році військові застосовували принципи надання допомоги постраждалим (BICEPS). Для цього створені так звані підрозділи відновлення боєздатності (Combat Fitness Retraining Unit), до складу яких входять психіатри, соціальні працівники, клінічні психологи, інструктори зі спорту та бойової підготовки. Важливою умовою $є$ те, що лікар або психолог, які надають допомогу, повинні обов'язково мати бойовий досвід, що дасть змогу встановити більш довірливі стосунки в процесі проведення терапії [16]. Використання принципів BICEPS під час надання допомоги постраждалим із проявами стресових розладів дає змогу повернути до служби майже 85\% особового складу, з них близько у 7\% можуть 
бути повторні реакції. В армії Ізраїлю під час війни в Лівані використовували три принципи 3 шести (наближеність, швидкість, очікуваність). Порівняння підрозділів, в яких дотримувалися таких принципів, показало, що близько 60 \% військових змогли повернутися до виконання професійних обов'язків, на противагу 22 \% там, де цих принципів не дотримувалися. Крім того, частина розвитку ПТСР виявилася нижче на $30 \%$. Показовими щодо зазначеного $\epsilon$ порівняльні дані поширеності ПТСР у ветеранів В'єтнамської війни $(15,2 \%$ після 15 років) і операції в Перській затоці (5\% після 2 років)[21].

Ізраїльська система психологічної підтримки складається 3 п'яти великих підрозділів: підрозділ діагностики, профілізації та профорієнтації; служба психологічної підтримки військовослужбовців; підрозділ із реабілітації та роботи 3 демобілізованими; служба підтримки цивільного населення при кризових ситуаціях; служба роботи з сім'ями постраждалих. Підрозділ діагностики, профілізації та профорієнтації - найбільший. Його представники відповідають за всебічне медичне обстеження молодих людей, починаючи від 15 років (включно 3 психологічним тестуванням) i формують медичну карту військового (профіль), що супроводжує його протягом життя. Зміни до карти можна внести лише протягом наступних трьох років після тестування. Первинна психологічна оцінка визначає: інтелектуальний рівень розвитку особистості, психологічний i соціальний статус, мотиваційні характеристики та лідерські якості. Всі показники заносять до особової картки, і на їхній основі здійснюється профорієнтація потенційного військовослужбовця в той чи інший рід військ. 3 огляду на те, що мотивація до служби в армії в Ізраїлі досить висока, вступити на військову службу можуть навіть призовники 3 інвалідністю, а також 3 психіатричним діагнозом, наприклад, 3 аутизмом, легкою формою дебільності, шизофренією в тривалій ремісії, синдромом Дауна, афективними розладами тощо. Для таких військовослужбовців розроблено спеціальні методики реабілітації та соціалізації в армійському середовищі. Втім, і це важливо розуміти, що армія - не клініка, і медичного супроводу такі військовослужбовці не отримують, але адаптуються вони іноді дуже успішно, і період ремісії в них помітно подовжується. У цьому випадку на армійських психологів і соціальних працівників покладається функція контролю, супроводу і розроблення програм адаптації i м'якої реабілітації таких військовослужбовців [14].

Ізраїльські військові психологи займаються і посткризовим тестуванням, яке проходять всі учасники бойових дій, i діагностикою бойової психічної травми та ПТСР. Підрозділ психологічної підтримки військовослужбовців займається поточною психологічною допомогою, яка спрямована $\mathrm{i}$ на розвиток стресостійкості особового складу, на формування його психологічної готовності до виконання службових і бойових завдань, i на надання психологічної допомоги військовослужбовцям та членам їхніх сімей, що зазнали впливу екстремальних чинників службової діяльності.

На особливу увагу заслуговує ізраїльська реабілітаційна програма військовослужбовців після демобілізації, спрямована на те, щоб жоден боєць не залишився наодинці навіть із незначною проблемою. Ця програма передбачає підготовку близьких i рідних демобілізованого до його повернення додому. Діяльність підрозділу з реабілітації та роботи 3 демобілізованими спрямована на розроблення реабілітаційних програм, створення та/або підтримку спеціальних центрів анонімної допомоги, супровід військовослужбовців з інвалідністю, супровід бійців із бойовою психічною травмою, надання соціальної допомоги.

Ізраїль має багаторічну вдосконалену систему допомоги цивільному населенню в умовах ведення бойових дій. $\mathrm{y}$ кожному мікрорайоні населених пунктів країни створено такі структури, як: добровільні штаби кризових ситуацій; пункти оповіщення населення; пункти термінової допомоги. За місцем проживання розміщено інформаційні банери, регулярно проводиться навчання, застосовується метод «хибних тривог», ведеться роз'яснювальна робота в школах і коледжах; для дітей молодшого віку розроблено спеціальні методики доведення інформації.

\section{Висновки}

1. Показано, що прояви як самого бойового i військово-професійного стресу, так і його дезадаптивних реакцій, а також умови їх виникнення не тільки підвищують ризики несприятливого перебігу бойових поранень, але й суттєво впливають на перебіг їх 
наслідків з боку психічного та фізичного здоров'я.

2. Потребують детального вивчення на практичному (натурному) рівні техніки психологічної допомоги на 1-му рівні (ешелоні), які за досвідом 3С Великобританії, дозволяють суттєво зберегти психічне здоров'я військовослужбовців. Показано, що однією 3 важливих складових якісної реабілітації, $є$ побудова ефективної комунікації між системою здійснення лікувально-евакуаційного процесу постраждалих від фізичних травм та поранень, орієнтованою на соматичні показання i критерії, та елементами системи охорони психічного здоров'я військовослужбовців.

Такий аспект $€$ актуальним на всіх рівнях надання медичної допомоги.

3. Назріла необхідність удосконалення державної системи комплексної реабілітації військовослужбовців, які беруть або брали участь в бойових діях та перенесли бойові та військово-професійні травми і поранення в частині, що стосується як програмних заходів, так і методів контролю ефективності та якості проведеної реабілітації. Це дозволить цілеспрямовано здійснювати заходи щодо забезпечення збереження фізичного i психічного здоров'я військовослужбовців, забезпечить профілактику ПСТР, буде сприяти підтримці готовності особового складу до виконання завдань за будь-яких змінах обстановки.

\section{Література}

1. Борисов Д.Н. Структура и динамика заболеваемости военнослужащих Вооруженных сил Российской Федерации в 2004-2013 гг. / Д.Н. Борисов, И.Т.Русев., Р.А. Коровин, A.M. Барановский // Medline.ru: рос. биомед. журн. Т.16. - С.587-595.

2. Бриндіков Ю.А. Зарубіжний досвід реабілітації військовослужбовців - учасників бойових дій // Збірник наук. праць. Вип. LXXVIII. T.2. - С.195-200.

3. Гаранян Н.Г. Когнитивно-бихевиоральная психотерапия посттравматического стрессового расстройства//Консультативная психология и психотерапия. - 2013. - № 3. - С. 46-72.

4. Дёмкин А.Д. Обзор системы медикопсихологического сопровождения в армии США/А.Д. Дёмкин, А.А. Марченко, А.Ю. Гончаренко // Мед.-биол. и соц.-психол. пробл. безопасности в чрезв. ситуациях. - 2016. - № 2. - С. 52-57.

5. Єна А. Актуальність і організаційні засади медико-психологічної реабілітації учасників антитерористичної операції /А.Єна, В.Маслюк, А.Сергієнко // Науковий журнал МОЗ України. 2014. - №1(5). - C.5-16.

6. Кадлер Х.С. Психодинамическая терапия посттравматического стрессового расстройства/ Х.С. Кадлер, А.С. Блэнк, Дж.Л. Крапник // Журн. практ. психологии и психоанализа. - 2005. Февраль (№ 3).

7. Караяни А. Психологическая реабилитация участников боевых действий / А. Караяни //под ред. А.Я.Караяни, М.Подольский. М., 2003. - 80 с.

8. Марченко А.А. Особенности диагностики невротических расстройств у военнослужащих/А.А. Марченко, А.Ю. Гончаренко, Краснов А.А. [и др.] // Вестн. рос. воен.-мед. акад. 2015. - № 1 (49). - С. 48-53.

9. Миров А. Организация психологического обеспечения в Вооружённых силах ФРГ: http: // factmil.com/ publ/ strana/germanija/ psikhicheskie_ zabolevanija

_voennosluzhashhikh_ bundesvera_2010/41-1-0-407.

10. Мухина Н.А., Евдокимов В.И. «Сексуальная травма в армии» как фактор риска посттравматического стрессового расстройства у женщин-ветеранов в США (обзор литературы) // Мед.-биол. и соц.-психол. пробл. безопасности в чрезв. ситуациях. - 2014. - № 3. - С. 84-93.

11.Организация психиатрической помощи во Франции// Нейрonews. - 2012. - №10 (45). - C. 4.

12.Основи реабілітаційної психології: подолання наслідків кризи. Навчальний посібник. Т.1 / за ред. Н. Пророк. - Київ, 2018. - Т.1. - 208 с.

13. Радецька Л. В. Особливості проявів бойових стресових розладів у поранених військовослужбовців Збройних Сил України учасників бойових дій / Л. В. Радецька, І. О. Лаба, А. I. Смачило та ін. // Медсестринство. - 2020. - № 4. - С. 23-26.

14.Фельдман А. Інтерв'ю // НейроNEWS: психоневрология и нейропсихиатрия. - № 9 (73)

15.Якубова Л. Структурно-функціональна модель соціальної реабілітації осіб, що повернулись із зони АТО // Молодь і ринок. - 2017.№ 5 (148). - С. 50-54.

16.Якушкин Н. Психологическая помощь воинам-«афганцам» в Республиканском центре Республики Беларусь / Н.Якушкин // Психол. Журн.. - 1996. - T.17, №5. - C.102-105.

17. Army U.S. Army Strategic Planning Guidance. Army Plan, 2014. -158 p.

18. Besemann MH. Physical rehabilitation following polytrauma. The Canadian Forces Physical Rehabilitation program 2008-2011. Can J Surg. 2011;54:S135-41. [PMC free article] [PubMed] [Google Scholar].

19. Gatchel R. Comorbidity of chronic pain and mental health disorders: the biopsychosocial perspective. Am Psychol. 2004; 59: 795-805. 
20.Greenberg N. A cluster randomized controlled trial to determine the efficacy of Trauma Risk Management (TRiM) in a military population. Journal of traumatic stress. 2010. Vol. 23. №4. P. 430-436.

21. Hall D. Stress, Suicide, and Military Service during operation Uphold Democracy/ D. Hall //Military Medicine. - 1996. №3. - P. 159-162.

22. Hammermeister J. Military applications of performance psychology methods and techniques: an overview of practice and research from the U. S. Army // J. of Performace Psychology. 2011. № 3. P. 56-62.

23. Harms, P.D. Report \#4: Evaluation of Resilience Training and Mental and Behavioral Outcomes // The Comprehensive Soldier and Family Fitness Program Evaluation. 2013.19 p.

24. Hotopf M. The health of UK military personnel who deployed to the 2003 Iraq war: a cohort study . Lancet 2006 ; 367 (9524) : P.1731 - 41 .

25. Hughes J. G. Use of psychological decompression in military operational environments . Mil Med 2008 173 (6) : P.534 - 8 .

26. Iversen A. Goodbye and good luck: the mental health needs and treatment experiences of British exservice personnel. Br J Psychiatry 2005. 186: 480 - 6 .

27. La santé mentale chez les vétérans canadiens : une mission de famille Rapport du Comité permanent des anciens combattants Le président Neil R. Ellis JUIN

\section{References}

1. Borisov, D.N., Rusev, I.T., Korovin, R.A., Baranovskiy, A.M. (2015). Struktura i dinamika zabolevayemosti voyennosluzhashchikh Vooruzhennykh sil Rossiyskoy Federatsii v 2004-2013 gg. [The structure and dynamics of morbidity in military personnel of the Armed Forces of the Russian Federation in 2004-2013]. Medline.ru: biomeditsinskiy zhurnal - biomedical journal (Vols 16), 587-595.

2. Bryndikov, Yu.A. (2017). Zarubizhnyy dosvid reabilitatsiyi viys'kovosluzhbovtsiv - uchasnykiv boyovykh diy [Foreign experience in the rehabilitation of combatants]. Zbirnyk nauk. prats' - Collection of Sciences (ed. LXXVIII. T.2), 195-200.

3. Garanyan, N.G. (2013). Kognitivnobikhevioral'naya psikhoterapiya posttravmaticheskogo stressovogo rasstroystva [Cognitive-behavioral psychotherapy of post-traumatic stress disorder]. Konsul'tativnaya psikhologiya i psikhoterapiya - Counseling psychology and psychotherapy (No.3), 46-72.

4. D. Domkin, A.A. Marchenko, A.Yu. Goncharenko (2016). Obzor sistemy mediko-psikhologicheskogo soprovozhdeniya $\mathrm{v}$ armii SShA [Review of the system of medical and psychological support in the US Army]. Med.biol. i sots.-psikhol. probl. bezopasnosti v chrezv. situatsiyakh - Med.-Biol. and social psychology. probl. security in emergency situations (No. 2), 52-57.

5. Yena, A., Maslyuk, V., Serhiyenko, A. (2014). Aktual'nist' i orhanizatsiyni zasady medykopsykholohichnoyi reabilitatsiyi uchasnykiv antyterorystychnoyi operatsiyi [Relevance and organizational principles of medical and psychological rehabilitation of participants in the anti-terrorist
2017 42e LÉGISLATURE, 1 re SESSION /http://www.parl.gc.ca

28. Le Service de santé royal canadien - Métiers Québec /www.metiers-quebec.org > s.

29. Martin J., Sparacino R., Belenky G. The Gulf War and Mental Health: A Comprehensive Guide. Westport : Greenwood, 1996. 28 p.

30. Pinder R. J. Mental health care provision in the UK armed forces. Military medicine. 2010.Vol. 175. №10. - P. 805-810.

31. Puchalski CM, Vitillo R, Hull SK, et al. Improving the spiritual dimension of whole person care: reaching national and international consensus. J Palliat Med. 2014;17: 642-56.

32. Sweeney PJ, Hannah ST, Snyder DM. The domain of the human spirit. In: Snyder DM, Matthews LJ, editors. Forging the warrior's character: Moral precepts from the cadet prayer. McGraw-Hill Higher Education; 2007.

33. Susskind O., Ruzek J. I., Friedman M. J. The VA/DOD clinical practice guideline for management of post-traumatic stress (update 2010): Development and methodology. Journal of Rehabiliation Research and Development, 2012 . $\quad \mathrm{T} \quad 49$. http://dx.doi.org/10.1682/JRRD.2011.12.0241

34.WHOQOL Group. The WHO quality of life assessment (WHOQOL) position paper from the World Health Organization. Soc Sci Med. 1995;41:1403-9.

operation]. Naukovyy zhurnal MOZ Ukrayiny - Scientific Journal of the Ministry of Health of Ukraine. (No.1 (5)), 5-16.

6. Kadler, H.S., Blénk, A.S., Krapnyk, Dzh.L. (2005). Psykhodynamycheskaya terapyya posttravmatycheskoho stressovoho rasstroystva [Psychodynamic therapy of post-traumatic stress disorder]. Zhurn. prakt. psykholohyy y psykhoanalyza Journal. practice. psychology and psychoanalysis. (February № 3).

7. Karayany, A.Ya., Podol'sky, M. (2003). Psykholohycheskaya reabylytatsyya uchastnykov boevykh deystvyy [Psychological rehabilitation of combatants]. Moscow, 80.

8. Marchenko, A.A., Honcharenko, A.Yu., Krasnov, A.A. (2015). Osobennosty dyahnostyky nevrotycheskykh rasstroystv u voennosluzhashchykh [Features of diagnosis of neurotic disorders in servicemen]. Vestn. ros. voen.-med. akad. - Military Medical Academy Bulletin. 1 (49), 48-53.

9. Mirov, A. (2010). Organizatsiya psikhologicheskogo obespecheniya v Vooruzhonnykh silakh FRG [Organization of psychological support in the Armed Forces of the Federal Republic of Germany]. http://factmil.com/publ/strana/germanija/

psikhicheskie__zabolevanija__voennosluzhashhikh_ bundesvera_2010/41-1-0-407.

10. Mukhina, N.A., Yevdokimov, V.I. (2014). «Seksual'naya travma $\mathrm{V}$ armii» kak faktor riska posttravmaticheskogo stressovogo rasstroystva $u$ zhenshchin-veteranov v SShA (obzor literatury) ["Sexual Trauma in the Army" as a Risk Factor for PTSD in Female Veterans in the United States (Literature 
Review)]. Med.-biol. i sots.-psikhol. probl. bezopasnosti v chrezv. Situatsiyakh - Med.-Biol. and social psychology. probl. of security in emergency situations, (3), 84-93.

11. Rodneva, I. (2012). Organizatsiya psikhiatricheskoy pomoshchi vo Frantsii [Organization of psychiatric care in France]. Neuronews. 10 (45), 4. https://neuronews.com.ua/ru/archive/2012/10\%28 45\%29/article-735/organizaciya-psihiatricheskoypomoshchi-vo-francii\#gsc.tab $=0$

12. Prorok, N. (ed.), (2018). Osnovi reabílítatsíynoí psikhologíi: podolannya naslídkív krizi [The basics of rehabilitation psychology: a lot of the legacy of the crisis]. Navchal'niy posíbnik, 1, Kyiv, 208.

13. Radets'ka, L.V., Laba, Í.O., Smachilo, A.Í. et all. (2020). Osoblivostí proyavív boyovikh stresovikh rozladív u poranenikh víys'kovosluzhbovtsív Zbroynikh Sil Ukraíni - uchasnikív boyovikh díy [Particularities of fighting stress disorders among wounded military servicemen of the Defense Forces of Ukraine - participants of fighting actions]. Medsestrinstvo - Nursing, (40), 23-26.

14.Fel'dman, A. (2015). Interv"yu [Interview]. NeyroNEWS: psykhonevrolohyya y neyropsykhyatryya NeuroNEWS: psychoneurology and neuropsychiatry,.9 (73).

https://neuronews.com.ua/ua/archive/2015/9\%287

3\%29/article-1596/albert-feldman-ochen-vazhno-

sozdat-takuyu-sistemu-pri-kotoroy-

voennosluzhashchiy-smog-by-poluchit-

psihologicheskuyu-pomoshch-na-vseh-etapah-

neseniya-sluzhby-i-posle-demobilizacii-\#gsc.tab=0

15. Yakubova, L. (2017). Strukturno-funktsional'na model' sotsial'noyi reabilitatsiyi osib, shcho povernulys' iz zony ATO [Structural and functional model of social rehabilitation of persons returning from the ATO zone]. Molod' i rynok - Youth and Market, . 5 (148), 50-54.

16. Yakushkyn, N. (1996). Psykholohycheskaya pomoshch' voynam-«afhantsam»v Respublykanskom tsentre Respublyky Belarus' [Psychological assistance to "Afghan" soldiers in the Republican Center of the Republic of Belarus]. Psykhol. Zhurn - Psychol. Journal, 17(5), 102-105.

17.Army U.S. (2014). Army Strategic Planning Guidance. Army Plan, 158

18. Besemann,M.H. (2011). Physical rehabilitation following polytrauma. The Canadian Forces Physical Rehabilitation program 2008-2011. Can J Surg, ( 54) 35-41.

19. Gatchel, R. (2004). Comorbidity of chronic pain and mental health disorders: the biopsychosocial perspective. Am Psychol., (59), 795-805.

20.Greenberg, N. A. (2010). Cluster randomized controlled trial to determine the efficacy of Trauma
Risk Management (TRiM) in a military population. Journal of traumatic stress. 23(4), 430-436.

21. Hall, D. (1996). Stress, Suicide, and Military Service during operation Uphold Democracy. Military Medicine, 3, 159-162.

22. Hammermeister, J. (2011). Military applications of performance psychology methods and techniques: an overview of practice and research from the. U. S. Army,. J. of Performace Psychology, 3, 56-62.

23. Harms, P.D. (2013). Evaluation of Resilience Training and Mental and Behavioral Outcomes. The Comprehensive Soldier and Family Fitness Program Evaluation, (Report №4), 19

24. Hotopf, M. (2006). The health of UK military personnel who deployed to the 2003 Iraq war: a cohort study. Lancet, 367 (9524), 1731 - 1741.

25. Hughes, J. G. (2008). Use of psychological decompression in military operational environments. Mil Med. 173 (6), 534 - 538.

26. Iversen, A. (2005). Goodbye and good luck: the mental health needs and treatment experiences of British ex-service personnel. Br J Psychiatry. 186, 480 486.

27. La santé mentale chez les vétérans canadiens: une mission de famille Rapport du Comité permanent des anciens combattants Le président Neil R. Ellis (JUIN 2017), 42e LÉGISLATURE, 1 re SESSION, http://www.parl.gc.ca

28. Le Service de santé royal canadien - Métiers Québec, www.metiers-quebec.org

29. Martin, J., Sparacino, R., Belenky, G. (1996). The Gulf War and Mental Health. A Comprehensive Guide. Westport. Greenwood, 28.

30. Pinder, R. J. (2010). Mental health care provision in the UK armed forces. Military medicine, 175 (10), 805-810.

31. Puchalski, C.M., Vitillo, R., Hull, S.K., et al. (2014). Improving the spiritual dimension of whole person care: reaching national and international consensus. $J$ Palliat Med, .17, 642-656.

32. Sweeney, P. J., Hannah, S. T., \& Snider, D. M. (2007). The domain of the human spirit. In D. M. Snider \& L. J. Matthews (Eds.), Forging the warrior's character: Moral precepts from the cadet prayer (pp. 5599).Sisters, OR: Jerico

33. Susskind, O., Ruzek, J. I., \& Friedman, M. J. (2012). The VA/DOD clinical practice guideline for management of post-traumatic stress (update 2010): Development and methodology. Journal of Rehabiliation Research and Development, 49. http://dx.doi.org/10.1682/JRRD.2011.12.0241

34.WHOQOL Group. The WHO quality of life assessment (WHOQOL) position paper from the World Health Organization (1995). Soc Sci Med. .41, 14031409. 


\title{
ОСОБЕННОСТИ ОРГАНИЗАЦИИ МЕДИКО-ПСИХОЛОИЧЕСКОЙ РЕАБИЛИТАЦИИ ВОЕННОСЛУЖАЩИХ В СТРАНАХ-ЧЛЕНАХ И ПАРТНЕРАХ НАТО
}

\author{
А.В. Швец ${ }^{1}$, О.В. Горишная ${ }^{1}$, А.Ю. Ких ${ }^{2}$, Г.В. Иванцова ${ }^{1}$, А.А. Горшков ${ }^{1}$, О.В. Рычка ${ }^{1}$
}

\author{
${ }^{1}$ Научно-исследовательский институт проблем военной медицины Ураинской военно-медицинской \\ академии, г. Киев, Украина \\ ${ }^{2}$ Военно-медицинский клинический лечебно-реабилитационный центр, г. Ирпень, Украина
}

\begin{abstract}
Цель. Исследовать различные аспекты организации медико-психологической реабилитации военнослужащих в странах - членах и партнерах НАТО.

Материалы и методы. C использованием методов системного, библиосемантического и ретроспективного анализа изучены научные публикации, в которых отражены особенности организации медико-психологической реабилитации военнослужащих США, Канады, Германии, Франции, Великобритании, Израиля. Для этого осуществлен поиск доступных источников информации с 1995 по 2017 годы, которые касались цели работы и терминологических фраз «Psycho-medical aid», «Psycho-medical rehabilitation», «Medical rehabilitation», «Psychiatric rehabilitation», «Psychological Rehabilitation». На основе thoughtful-анализа современных источников информации были обобщены разные подходы к формированию и поддержанию надлежащего уровня ментального здоровья с целью разработки и усовершенствования отечественных мероприятий медико-психологической реабилитации военнослужащих.
\end{abstract}

Результаты. Выявлены особенности организации медико-психологической реабилитации военнослужащих в ВС США, Канады, Германии, Франции, Великобритании, Израиля. Показана важность научно-методического обеспечения системы контроля боевого стресса в армии США, которое обеспечивают научные центры по контролю боевого и военно-профессионального стресса родов войск и ведущие научные университетские центры США. Наиболее активными участниками исследовательских программ по ПТСР в США являются Национальный институт психического здоровья (NIMH), Национальный центр по проблемам ПТСР (US Department of Veterans Affairs), Центр психологического здоровья Минобороны (DCEPH TBI DCoE), Военно-медицинский университет (USUHS), Военный институт uм. Уолтера Рuда (WRAIR). Отмечено необходимость внедрения современных инструментов скрининга эффективности реабилитации (шкала Ренкина, специальные компьютерные программы и т.n.) с учетом Международной классификации функционирования и ограничения жизнедеятельности.

Выводы. Показано, что проявления как боевого и военно-профессионального стресса, так и его дезадаптивных реакций, а также условия их возникновения не только повышают риски неблагоприятного течения боевых ранений, но и оказывают существенное влияние на течение их последствий со стороны психического и физического здоровья. Поэтому данный аспект организации медико-психологической реабилитации из опыта организации медико-психологической реабилитации военнослужащих $в$ вооруженных силах ведущих стран-членов и партнеров НАТО является одним из принципиальных для внедрения в ВС Украины. Детального изучения на практическом (натурном) уровне требуют техники психологической помощи на 1-м уровне (эшелоне), которые по опыту ВС Великобритании, позволяют существенно сохранить психическое здоровье военнослужащих. Показано, что одной из важных составляющих качественной реабилитации является построение эффективной коммуникации между системой осуществления лечебно-эвакуационного процесса пострадавших от физических травм и ранений, ориентированной на соматические показания и критерии, и элементами системы охраны психического здоровья военнослужащих; данный аспект актуален на всех уровнях оказания медицинской помощи. Назрела необходимость усовершенствования государственной системы комплексной реабилитации военнослужащих, участвующих в боевых действиях и перенесших боевые и военно-профессиональные травмы и ранения, в части, касающейся как программных мероприятий, так и методов контроля эффективности и качества проводимой реабилитации. Это позволит целенаправленно осуществлять мероприятия по обеспечению сохранения физического и психического здоровья военнослужащих, обеспечит профилактику ПСТР, будет способствовать поддержанию готовности личного состава к выполнению задач при любых изменениях обстановки.

Ключевые слова: медико-психологическая реабилитация, медико-психологическое сопровождение, психическое здоровье. 


\title{
PECULIARITIES OF THE ORGANIZATION OF PSYCHO-MEDICAL REHABILITATION OF SERVICEMEN IN NATO MEMBER COUNTRIES AND PARTNERSHIP FOR PEACE COUNTRIES
}

\author{
A.V.Shvets ${ }^{1}$, 0.V. Horishna1, A. Yu. Kikh², G.V. Ivantzova' ${ }^{1}$, O. O. Gorshkov' ${ }^{1}$, O.V. Richka1 \\ ${ }^{1}$ Ukraine military-medical academy, Research Institute of Military Medicine, Kyiv, Ukraine \\ ${ }^{2}$ Military Medical Clinical Treatment \& Rehabilitation Center, Irpin, Ukraine
}

The purpouse. To discover various aspects of the organization of psycho-medical rehabilitation of military personnel in NATO member and partner countries.

Materials and methods. Scientific publications have been studied using the methods of systemic, bibliosemantic and retrospective analysis, which reflect the features of the organization of psycho-medical rehabilitation of servicemen in the USA, Canada, Germany, France, Great Britain, Israel. A research was carried out for available sources of information from 1995 to 2017, which related to the purpose of the work and terminological phrases «Psycho-medical aid», "Psycho-medical rehabilitation», "Medical rehabilitation», "Psychiatric rehabilitation», "Psychological Rehabilitation». Based on a thoughtful-analysis of modern sources of information, various approaches to the formation and maintenance of an appropriate level of mental health care and rehabilitation have been summarized.

Results. The features of the organization of psycho-medical rehabilitation of servicemen in the Armed Forces of the USA, Canada, Germany, France, Great Britain, Israel have been revealed. The importance of scientific and methodological support of the Combat and Operational Stress Control system in the US Army, which is provided by the scientific centers for the control of combat and military-professional stress of the combat environtment and the leading scientific university centers of the United States, has been shown. The most active participants in PTSD research programs in the United States are the National Institute of Mental Health (NIMH), the US Department of Veterans Affairs, the Center for Mental Health of U.S. Department of Defense (DCEPH TBI DCoE), the University of Military Medicine (USUHS), the Walter Reed Army Institute of Research (WRAIR). The need to introduce modern screening tools for the effectiveness of rehabilitation (Rankine scale /mRS/, special computer programs, etc.), taking into account the International Classification of Functioning and Disability, has been noted. The main trend in the organization of an effective system for maintaining the mental health of servicemen in NATO is the introduction of appropriate training programs to increase the level of psychological resilience of personnel, expanding knowledge among servicemen about cognitive, behavioral and physiological processes in combat, normalization of stress response, providing servicemen with effective coping strategies to overcome stress and assist commanders in maintaining and strengthening the mental health of subordinates.

Conclusions. It was shown that the manifestations of combat and military-professional stress, as well as its maladaptive reactions, as well as the conditions of their occurrence not only increased the risk of adverse combat injuries, but also significantly affected the course of their consequences for mental and physical health. This aspect of organization of psycho-medical rehabilitation of military personnel in the armed forces of the leading NATO member countries and partnership for peace countries is one of the fundamental aspects for implementation in the Armed Forces of Ukraine. A detailed study at a practical level requires psychological assistance techniques at the 1st Role, which, according to the experience of the British Armed Forces, can significantly preserve the mental health of servicemen. One of the important components of high-quality rehabilitation is the construction of effective communication between the system for the implementation of the medical and evacuation process of victims of physical trauma and wounds and the elements of the mental health system of servicemen. This aspect is relevant at all levels of medical care. There is a need to improve the state system of comprehensive rehabilitation of servicemen participating in hostilities and having suffered combat and military occupational injuries and wounds. This applies to both program activities and methods of monitoring the effectiveness and quality of the ongoing rehabilitation. Such measures will make it possible to purposefully carry out measures to ensure the preservation of the physical and mental health of servicemen, ensure the prevention of PSTD, and will help maintain the readiness of personnel to perform tasks in any operational changes.

Key words: psycho-medical rehabilitation, medical and psychological support, mental health.

Конфлікт інтересів: відсутній.

Conflicts of interest: authors have no conflict of interest to declare.

\section{Відомості про авторів:}

Швець А. В., А, с, D, E, F - полковник медичної служби, д. мед. Н, професор, заступник начальника Української військово-медичної академії з наукової роботи, м. Київ.

Горішна О.В., C, D, Е - д. мед. н., доцент, провідний науковий співробітник науково-дослідного відділу (профілактичної медицини) Науково-дослідного інституту проблем військової медицини Української військово-медичної академії, м. Київ. 
Кіх А.Ю. в, с, D - полковник медичної служби, к. мед. н., начальник Військово-медичного клінічного лікувально-реабілітаційного центру, м. Ірпінь.

Іванцова Г.В., в, С, D - к. мед. н., с.н.с., молодший науковий співробітник науково-дослідного відділу Науково-дослідного інституту проблем військової медицини Української військово-медичної академії, м. Київ.

Горшков 0.0., в, C, D - капітан медичної служби, науковий співробітник науково-дослідного відділу Науково-дослідного інституту проблем військової медицини Української військово-медичної академії, м. Київ.

Ричка О.В. B, C, D - науковий співробітник науково-дослідного відділу Науково-дослідного інституту проблем військової медицини Української військово-медичної академії, м. Київ.

$A$ - концепція та дизайн дослідження; $B$ - збір даних; $C$ - аналіз та інтерпретація даних;

$D$ - написання статmi; $E$ - редагування статmі; F- остаточне затвердження статті

\section{Сведения об авторах:}

Швец А. В., - полковник медицинской службы, д. мед. н., профессор, заместитель начальника Украинской военно-медицинской академии по научной работе, г. Киев.

Горишная О.В., - д. мед. н., доцент, ведущий научный сотрудник научно-исследовательского отдела (профилактической медицины) Научно-исследовательский институт проблем военной медицины Украинской военно-медицинской академии, г. Киев.

Ких А.Ю., - полковник медицинской службы, к. мед. н., начальник Военно-медицинского клинического лечебно-реабилитационного центра, г. Ирпень.

Иванцова Г.В., - к. мед. н., с.н.с., младший научный сотрудник научно-исследовательского отдела Научно-исследовательского института проблем военной медицины Украинской военно-медицинской академии, г. Киев.

Горшков А.А., - капитан медицинской службы, научный сотрудник научно-исследовательского отдела Научно-исследовательского института проблем военной медицины Украинской военномедицинской академии, г. Киев.

Рычка О.В. - научный сотрудник Научно-исследовательского отдела Научно-исследовательского института проблем военной медицины Украинской военно-медицинской академии, г. Киев.

\section{Information about authors:}

Shvets A. V., A, C, D, E, F - Col. MS, MD, DSc, professor, Deputy chief of Ukrainian Military Medical Academy for sciense, Kyiv, E-mail: shvetsandro@gmail.com, https://orcid.org/0000-0002-9461-7129

Horishna O.V. C, D, E, F - MD, DSc, Associate Professor, Leading Researcher of the Research Department (Preventive Medicine) of the Research Institute of Military Medicine of the Ukrainian Military Medical Academy, Kyiv: https://orcid.org/0000-0003-1362-4536

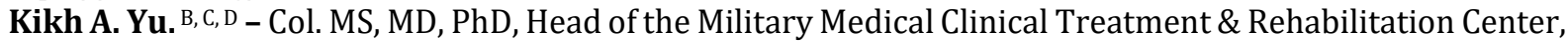
Irpin. https://orcid.org/0000-0003-1746-7996

Ivantzova G.V., B, C, D - Junior Researcher of the Research Department of the Research Institute of Military Medicine of the Ukrainian Military Medical Academy, Kyiv. https://orcid.org/0000-0002-5394-4676

Gorshkov 0. 0. B, C, D - Cpt MS, Researcher of the Research Department of the Research Institute of Military Medicine of the Ukrainian Military Medical Academy, Kyiv. https://orcid.org/0000-0001-9584-1889

Richka O.V. B, C, D - Researcher of the Research Department of the Research Institute of Military Medicine of the Ukrainian Military Medical Academy, Kyiv: https://orcid.org/0000-0001-8950-3488

$A$ - research concept and design; $B$ - collection and/or assembly of data; $C$ - data analysis and interpretation;

$D$ - writing the article; $E$ - critical revision of the article; $F$ - final approval of the article.

Адреса для листування: вул. Московська, 45/1, буд. 33, м. Київ, 01015

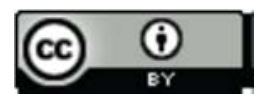

